\title{
PYROXENITE AND DUNITE XENOLITHS AS METAMORPHOSED CUMULATES FROM THE ARCHEAN LOWER OCEAN CRUST
}

\author{
Stephen F.Foley ${ }^{1}$, Stephan Buhre ${ }^{* 2}$, Dorrit E.Jacob ${ }^{1}$ and Tatjana Rehfeldt ${ }^{1}$ \\ ${ }^{1}$ University of Greifswald, Germany; ${ }^{2}$ University of Frankfurt-am-Main, Germany
}

\section{MODELS FOR THE ORIGIN OF DUNITES AND PYROXENITES}

In contrast to the large literature about granular and sheared peridotites, pyroxenites and especially dunite xenoliths in kimberlites have received relatively little attention. Dunite xenoliths form two geochemical groups; firstly, strongly depleted dunites with $\mathrm{Mg \#}$ $(100 \mathrm{Mg} /(\mathrm{Mg}+\mathrm{Fe}))$ of $93-95$, often with coarse-grained texture, and secondly, cumulate dunites with $\mathrm{Mg \#}$ between 88 and 90 (Harte and Hawkesworth, 1989). Models for their origin fall into three categories: (1) dunites are restites after extreme depletion of peridotitic starting material owing to high-degree partial melting; (2) dunites are cumulates formed in dykes or larger intrusions; and (3) dunites are reaction products formed by flow of olivine-saturated melts through pyroxenerich ultramafic rocks (Quick, 1981; Harte and Hawkesworth, 1989).

Residual dunites occur together with harzburgites and may be formed near subduction zones (Kubo, 2002). Cumulate dunites may be crystallized in larger intrusions or on the walls of emplacement channels. The latter origin corresponds to a large proportion of dunite xenoliths in basalts, as can be recognized by their lower Mg\# (White, 1966; Kirby and Green, 1980). Dunites originating as reaction products are now extensively described from ophiolites as being formed in former melt channels in which melts approached the surface (Kelemen et al., 1995).

Pyroxenites and wehrlites are mineralogically more diverse, and their origins are probably correspondingly mixed. For example, two groups are recognized as xenoliths from the Eifel area in Germany; olivine+clinopyroxene veins originate at higher temperatures, whereas mica- and amphibole-bearing pyroxenites indicate lower temperatures (WittEickschen and Kramm, 1998). Pyroxenites occur as bands and veins within peridotites, and as discrete and composite xenoliths, often containing garnet or spinel. Cumulate pyroxenites should be recognizable by their lower $\mathrm{Mg \#}$ and higher contents of $\mathrm{Al}, \mathrm{Ca}$ and $\mathrm{Ti}$ (Downes, 2001), and their chemistry may characterize the melts from which they formed (Irving, 1980). Models for the origin of pyroxenites generally see them as either crystallized from mantle-derived melts, or as seawater-altered subducted oceanic crust (Allègre and Turcotte, 1986).

\section{DUNITES AND PYROXENITES FROM THE ARCHEAN OCEANIC CRUST}

Here, we advance the hypothesis that many pyroxenites and dunites may be the metamorphosed products of ultramafic cumulates formed at the base of thick ocean crust during the late Archean (Foley et al., 2003). This differs from the hypothesis of recycled oceanic crust in that the origin is too deep in the oceanic crust for the protoliths to be hydrothermally altered by seawater. However, any dunites and pyroxenites formed in the way suggested here would be more correctly considered as being related to the eclogite suite than to the peridotite suite, as their origin and preservation is closely tied to the choked subduction of oceanic crust.

The thickness of the ocean crust in the Archean is a function of the mantle temperature, which is very poorly known - estimates vary from little hotter than today to much higher temperatures that would imply crustal thickness well in excess of $30 \mathrm{~km}$. Many eclogite xenoliths have been shown to represent basaltic to picritic parts of the ocean crust and their associated gabbros. They are apparently restricted in age to the late Archean, and indicate that mantle temperatures during the period 3.0 to $2.5 \mathrm{Ga}$ were probably at the lower end of the ranges mentioned above, and that primary midocean ridge melts were picritic, not komatiitic.

\section{FORWARD MODELLING OF THE FORMATION OF ARCHEAN OCEANIC CRUSTAL}

So how did the formation and constitution of the oceanic crust differ in the late Archean from modern times? A realistic scenario is shown in Figure 1 on the basis of forward modelling by numerical "fractionation" of primary picritic melts with the program "pmelts" (Farnetani et al., 1996; Schmickler et al., 2003). This 
indicates that a $20 \mathrm{~km}$ thick oceanic crust would consist of about $30 \%$ by volume of ultramafic cumulates forming the lower $6-7 \mathrm{~km}$. Above this, basalts, gabbros and other plagioclase-rich intrusive rocks dominate. This means that even komatiitic parental melts would produce a large proportion of basaltic products. became gradually thinner until a threshold was reached, after which the whole crust could be subducted (Fig.1, lower panel). This is required by the trace element partitioning constraint that tonalitic-trondhjemitic crust must be produced by melting of amphibolite and not eclogite (Foley et al., 2002).

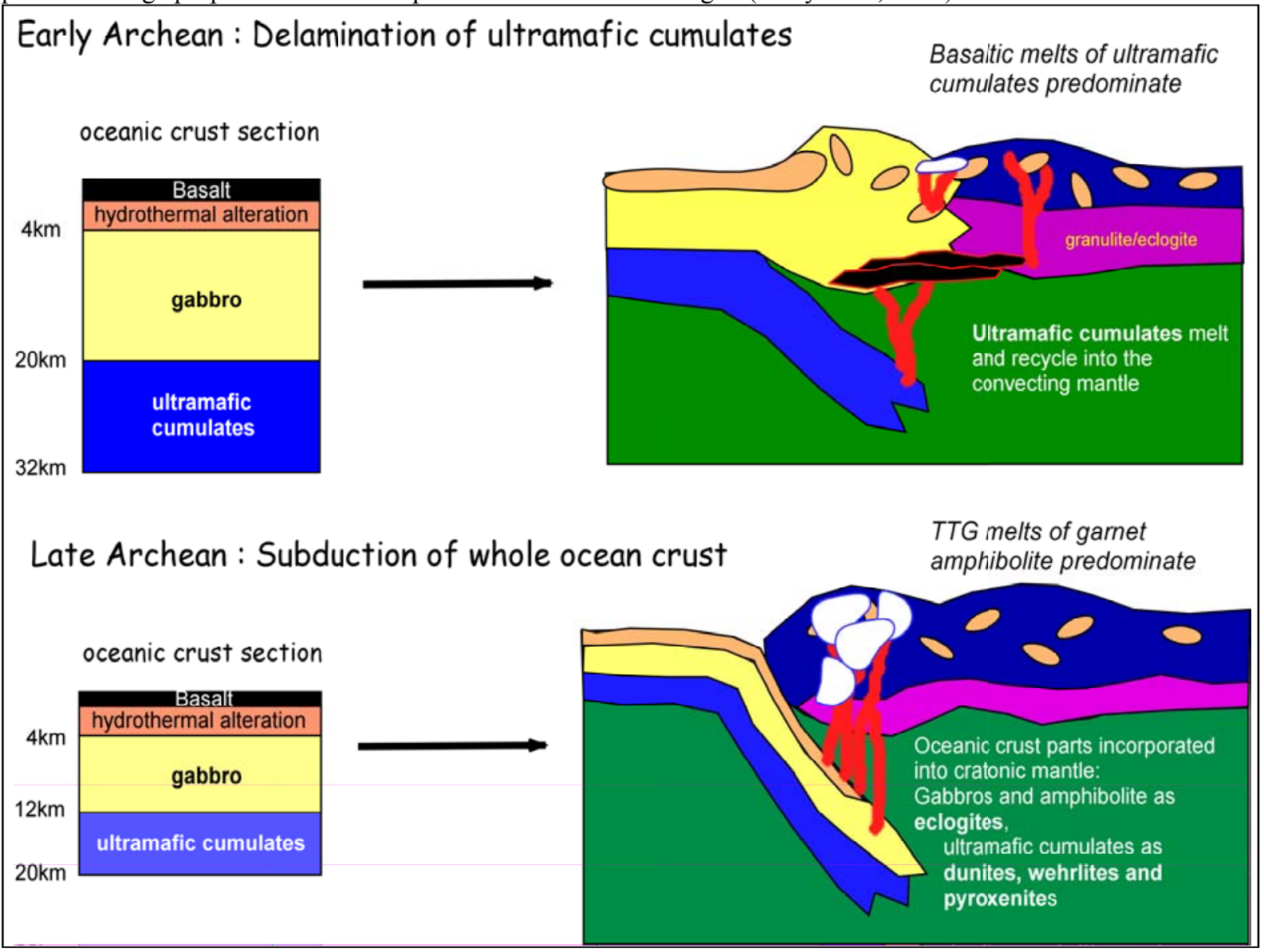

Figure 1: Model for the contrasting fates of oceanic crust in the early and late Archean. Ultramafic cumulates form several kilometers of the lower oceanic crust. During the early Archean, they are delaminated and remixed into the mantle, whereas in the late Archean they can be incorporated into the developing cratonic mantle, together with eclogite xenoliths, which are genetically related. Modified from Foley et al., (2003).

As the Earth cooled throughout the Archean, the volume and $\mathrm{MgO}$-content of melts produced at midocean ridges decreased continuously: in the early Archean, the crust was too thick to be subducted as a unit, and so it split, with the lower part consisting of ultramafic cumulates being "subducted" and remixed into the convecting mantle (Figure 1, upper panel). Towards the end of the Archean, the oceanic crust
The original mineralogy of the ultramafic cumulates depends on the $\mathrm{MgO}$ content of the primary melt and the depth at which fractionation occurs, which are to some extent related. Melts derived from deeper levels have higher normative olivine contents and so would lead to olivine-richer cumulates at shallower levels. However, the thicker crust in the early Archean may have favoured fractionation at the base of the crust at higher pressure, where the amount of olivine is reduced owing to its restricted pressure stability. Cumulates would be olivine-dominated at pressures of $0.3-0.5 \mathrm{GPa}$ (Farnetani et al., 1996), but may become pyroxenitic at higher pressures (Schmickler et al., 2003). 


\section{EXPERIMENTS ON METAMORPHISM AND PRESERVATION POTENTIAL}

The final assemblage produced from ultramafic and mafic cumulates formed in the oceanic crust depends on the metamorphic reactions encountered during subduction. Furthermore, their preservation as blocks in the cratonic lithosphere that could be later sampled as xenoliths depends on concurrent formation of cratonic lithosphere with the subduction scenario shown in Figure 1.

Our high-pressure experiments on a composition with $18 \mathrm{wt} \% \mathrm{MgO}$ show that all metamorphic products of olivine- and clinopyroxene-rich cumulates are plagioclase-free, and can never transform to eclogite. Instead, their metamorphic products are dunites, wehrlites and pyroxenites. The density increase during subduction metamorphism is much smaller than that experienced by basalts during the gabbro-eclogite transformation, so that the tendency for their incorporation into the developing cratonic lithosphere as dunite and pyroxenite is large. Further consequences of this scenario for the development of continental crust and the subduction process, as well as for convection in the mantle are outlined in Foley et al. (2003).

\section{RELATION TO THE ECLOGITE XENOLITH SUITE}

Pyroxenites and dunites formed in this way should be distinguishable from those formed as solid residua after extensive partial melting of fertile mantle peridotite, by reaction of melts with wall-rocks, or by the other cumulate scenarios outlined above. Their compatible trace element concentrations will be lower than residua after mantle melting, and contents of moderately incompatible elements, such as lithium, will be higher. Dunites and pyroxenites that originate as ultramafic cumulates in the lower parts of thick Archean oceanic crust form a suite that has been overlooked until now, but may turn out to be quite common.

\section{REFERENCES}

Allègre C.J., Turcotte, D.L., 1986. Implication of a twocomponent marble-cake mantle. Nature 323, 123 127.

Downes, H. 2001. Formation and Modification of the Shallow Sub-continental Lithospheric Mantle: a Review of Geochemical Evidence from Ultramafic Xenolith Suits and Tectonically Emplaced Ultramafic
Massifs of Western and Central Europe. J. Petrol. $42,233-250$.

Farnetani C.G., Richards, M.A., Ghiorso, M.S., 1996. Petrological models of magma evolution and deep crustal structure beneath hot spots and flood basalt provinces. Earth Planet. Sci. Lett. 143, 81-94.

Foley S.F., Tiepolo M., Vannucci R., 2002. Growth of early continental crust in subduction zones controlled by melting of amphibolite. Nature 417, 837-840.

Foley S.F., Buhre S., Jacob, D.E., 2003. Evolution of Archaean crust by delamination and shallow subduction. Nature 421, 249-252.

Harte, B., Hawkesworth, C.J. 1989. Mantle domains and mantle xenoliths. In J. Ross, (Ed.) Kimberlites and Related rocks. Blackwell, Melbourne. pp. 649-686.

Irving, A.J., 1980. Petrology and geochemistry of composite ultramafic xenoliths in alkalic basalts and implications for magmatic processes within the mantle. Amer. J. Sci. 280-A, 389-426.

Kelemen P.B., Shimizu, N., Salters, V.J.M., 1995. Extraction of mid-ocean-ridge basalt from the upwelling mantle by focused flow of melt in dunite channels. Nature 375, 747-753.

Kubo K., 2002. Dunite formation processes in highly depleted peridotite: case study of the Icanaidake peridotite, Hokkaido, Japan. J. Petrol., 43, 423-448.

Quick J.E., 1981. The origin and significance of large, tabular dunite bodies in the Trinity Peridotite, Northern California. Contrib. Mineral. Petrol. 78, 413-422.

Schmickler B., Jacob, D.E., Foley, S.F. 2003. Eclogite xenoliths from the Kuruman kimberlites, South Africa. 2. Geochemical fingerprinting of cumulate processes in thick crust. Lithos (submitted).

White R.W., 1966. Ultramafic Inclusions in Basaltic Rocks from Hawaii. Contrib. Mineral. Petrol. 12, 245-314.

Witt-Eickschen, G., Kramm, U., 1998. Evidence for the multiple stage evolution of the subcontinental lithospheric mantle beneath the Eifel (Germany) from pyroxenite and composite pyroxenite/ peridotite xenoliths. Contrib. Mineral. Petrol. 131, 258-272.

Contact: SF Foley, Institute of Geological Sciences, University of Greifswald, Jahnstrasse 17a, 17487 Greifswald, Germany.sfoley@uni-greifswald.de 